\title{
A NOTE ON THE NAMIBIAN NATIONAL ASSEMBLY ELECTIONS OF 2009
}

\author{
Lesley Blaauw
}

Dr Lesley Blaauw is a lecturer in International Relations and Political Economy and Head of the Department of Political and Administrative Studies at the University of Namibia

e-mail: lblaauw@unam.na

\begin{abstract}
This paper argues that the general elections of 2009 managed to consolidate the hold of the South West Africa People's Organisation (Swapo) on the body politic in Namibia. The expectation and perception that the formation of a new opposition party, by former members of the ruling party, would challenge the dominance of the ruling party has not materialised. What has transpired is that the Rally for Democracy and Progress has eroded the support of the Congress of Democrats $(\mathrm{CoD})$ and has replaced it as the official opposition. This situation is a repetition of that in 2004, when the $C o D$, as a newly formed opposition party, displaced the Democratic Turnhalle Alliance (DTA) as the major opposition party. The pattern of electoral politics reveals that the formation of opposition parties does not necessarily translate into a loss for the ruling party. The incumbency advantage enjoyed by Swapo seems to explain this. Furthermore, this paper posits the theory that the institutional mechanisms put in place to ensure free and fair elections require fundamental changes. What is also critical for electoral politics to succeed and for democracy to be consolidated in Namibia is that the political playing field needs to be extended in terms of media coverage for opposition parties and the provision of adequate funding, without which these parties will be unable to function properly.
\end{abstract}

\section{INTRODUCTION}

Electoral democracy seems to be the edifice upon which democracy is built in Namibia. This has endowed competitive elections in the country with special significance. To be sure, in Namibia, the ruling party, the South West African People's Organisation (Swapo), has enjoyed broad-based public support, 
ostensibly because it has been able to allow for the conduct of elections at regular intervals since the country attained independence in March 1990.

Namibia's fifth set of national polls, the national and presidential elections held from 27-28 November 2009 took place in the aftermath of the formation, in 2007, of yet another new opposition party, with credible leaders. The establishment of a new opposition party, The Rally for Democracy and Progress (RDP), followed the formation in the second half of the 1990s of the Congress of Democrats (COD), which, it was hoped, would challenge the dominance of the ruling party, Swapo, at the national level during the elections in 2004. To be sure, this perception was premised on the assumption that renewal in any democratic system normally takes place through elections (Adejumobi 2000). This paper will illustrate, however, that, as in preceding elections, the ruling party has been able to consolidate its hold on power.

This article posits that while effective electoral governance is crucial in securing credible elections, electoral democracy in Namibia, as illustrated by the national elections of 2009, is flawed in a number of respects. Towards that end, it contends that there is a serious need to look at the broad institutional framework of electoral governance in Namibia. To achieve the above-outlined objective, the paper looks at election administrative preparations, the campaigning process, the reporting of results, and the adjudication of electoral disputes in the country.

\section{ELECTORAL ADMINISTRATIVE PREPARATIONS AND MANAGEMENT}

Elections in Namibia are administered by an electoral commission and a directorate. The commission's constitution gives it a degree of administrative and political autonomy. The Electoral Commission of Namibia (ECN) was established by the Electoral Act, No 24 of 1992. Formed to replace an ad hoc election administration body created in 1989 , the ECN is the highest independent electoral body and is only answerable to Parliament (UNDP 2000, p 42).

The ECN replaced the United Nations, which was not only responsible for the transition period between 1989 and 1990 but was also instrumental in the running of the 1989 elections, which culminated in the election of the Constituent Assembly (Bauer 1999, p 430). The commission was administered as part of the Prime Minister's Office from 1992 to1998, but legal reform in 1998 ensured that it gained independence from the executive (Bauer 1999, p 430). The implications of these reforms are that the ECN now has full responsibility for the conduct of elections and that it is directly responsible to Parliament (UNDP 2000, p 42).

The ECN comprises a chairperson and four commissioners. A selection committee, which is appointed by the president, makes a short list of people suitable to be members of the ECN following a public announcement of the 
vacancies and a call for application. The selection committee comprises a judge nominated by the chief justice, a nominee of the ombudsman and a lawyer nominated by the law society. The directorate is staffed by a director, a deputy, and more than 10 employees from the civil service. By contrast, the posts of electoral commissioners and director of elections under the 1998 reform are filled through public competition (UNDP 2000, p 204). The Electoral Act stipulates that members of the ECN may lose their positions because of incapacity or may be removed by the president for misconduct, with the approval of a resolution of the National Assembly. In general, in its recruitment, the directorate attempts to reflect the social composition of the population, and makes a special effort to employ unemployed literate people (Tötemeyer, Weehmhörner \& Weiland 1996).

Article 4 (1) of the Electoral Act specifies the functions of the ECN pertaining to presidential, National Assembly, regional councils and local authority elections as controlling the:

- registration of voters;

- compilation and publication of the voters' roll;

- implementation of the code of conduct agreed upon by political parties;

- appointment of election officers;

- registration of political parties;

- supervision of elections;

- oversight of civic and voter education.

The Act provides that the commission shall consist of a judge or former judge of the Supreme Court or High Court, who shall be the chairperson of the commission; and four persons as the other members of the Commission.

Recent changes have resulted in alterations in the appointment of commissioners. For all future appointments the following procedure must be followed (Electoral Amendment Act 1998):

- The director invites applications for appointment to the commission by a notice in the Gazette and in two daily newspapers with a national circulation.

- A selection committee is assembled. Its members must include one staff member of the Supreme Court or of the High Court nominated by the Law Society of Namibia, one person from the staff of the ombudsman nominated by the ombudsman.

- The Supreme Court staff member serves as chairperson of the 
selection committee and the lawyer as the deputy chairperson. The committee is appointed for one year.

- The director convenes a meeting of the selection committee, which selects from the applications between 10 and 20 candidates for interviews. If there are fewer than 10 applications the director may invite any person to apply.

- The interviews are held during a meeting of the selection committee, which must be open to the public. The director must publicise the interviews and details of the applications in the Gazette before the meeting.

- Qualifications and criteria for appointment to the commission are subject to determination by the Standing Committee on Privileges of Parliament.

- Registered voters may submit written objections to any application and may be called to the meeting to answer questions.

- Applicants who fail to attend the meeting, or who answer questions untruthfully, are disqualified.

- Within ten days of the interviews the selection committee must recommend eight applicants to the president, who chooses five of them.

- If the director fails to follow the proper procedure for convening the interviews the president may appoint the commission on the recommendation of the Standing Committee on Privileges of Parliament.

The incumbent 2009 commissioners were appointed by the president for a period of five years and may be reappointed by the president for a similar period. In 2009 the members of the ECN were: Mr Victor Tonchi (chairperson), Ms Notemba Tjipueja, Ms Rosa Shipiki-Kapolo, Mr Shafimana Ueitele and Mr Lazarus Shatipamba.

The day-to-day operation of the commission is executed by the directorate of elections, which is responsible for the administrative and clerical work involved in the performance of the functions of the commission. Its director is an appointed public servant.

Voters are registered in their local authority areas, if these have been proclaimed, and in their regional council constituencies. The card issued for regional council elections is also used for National Assembly and presidential elections. The Ministry of Home Affairs, which is responsible for submitting monthly a list of deaths, did not do so during the period preceding the 2009 elections. The Namibian (2 November 2009) revealed that in 2009, and partly due 
to the failure of Home Affairs to submit the list, the voters' roll contained the names of a number of dead people.

Between 17 and 30 September 2009 a special 'supplementary registration' process took place. Initially, the ECN experienced problems in getting the 'supplementary registration' process under way because of the absence of voter registration material and printers for voter cards. The director of the ECN attributed this delay to a strike by customs workers in South Africa (The Namibian 21 September 2009). Such chaos in the voter registration process has implications for democratic politics in Namibia since election management bodies, like the ECN: '... are the principal instruments for organizing credible election processes, linking voters and governments in structured exchanges of support and policy, authority, and accountability' (Mozaffar 2002, p 90).

Notwithstanding these difficulties the supplementary registration process resulted in an increase in voter registration numbers by 300000 people, although the increases were unevenly spread between and among regions (see Table 1). The increased numbers meant that the number of eligible voters rose to 1.3 million. Needless to say, this figure was disputed by opposition parties. After a data cleanup 150000 names were removed from the voters' roll (IPPR 2009, p 2). Supplementary registration was encouraged through both print and electronic media and by means of posters and the voters' roll was available for inspection from 12-16 October 2009.

The ECN is also charged with the responsibility for allocating government money to political parties. In the period 2009 to 2012 political parties will receive more than N\$156-million. Currently 0,2 per cent of the total state revenue from the previous financial year is allocated to funding political parties. This amount is then divided among parties in the National Assembly based proportionately on the number of votes they received in the previous election. In 2008 Swapo, with 55 seats, received $\mathrm{N} \$ 12,5$-million; the $\mathrm{CoD}$, with five seats, received $\mathrm{N} \$ 1,1-$ million; the DTA, which won four seats, received N\$916 000; the National Unity Democratic Organisation (NUDO) and the United Democratic Front (UDF), with three seats each, received N\$687 000 and the Republican Party (RP) and the Monitor Action Group (MAG), with one seat each, received N\$229 000.

The current Electoral Act only requires parties to disclose foreign funding. In the event that a party refuses to disclose its foreign funding, the Electoral Commission of Namibia can cancel its registration. In addition, the party can be fined $\mathrm{N} \$ 12000$ and/or a prison sentence of three years may be imposed on the leaders of such parties (The Namibian 8 March 2010). Because of its dominance in political life Swapo receives the largest amount of funding from corporate entities. In addition, it owns a number of companies which provide funding and membership fees provide an additional source of income. 
Funding and other issues have been the source of severe criticism of the functioning and impartiality of the ECN. In 2008, for instance, the commission fired its director, Philemon Kanime, and his deputy, Ananias Elago. The official reason was negligence relating to the withholding of information critical to the Omuthiya local elections. The move attracted severe criticism of Swapo from the RDP. The ECN was again criticised by opposition parties in June 2009, after six ballot boxes were discovered at the Windhoek Central police station, reinforcing the perception that the electoral body is not very effective in dealing with elections.

Civil society organisations in Namibia have criticised the electoral body for excluding them from consultations on the amendment to the Electoral Bill which was tabled in Parliament in July 2009. Among the proposals is that votes should be counted at polling stations. There are, however, several loopholes in the Amendment Bill. Firstly, it severely restricts the pre-election role of election observers, only allowing them to observe voting, the counting process and the announcement of the results. Secondly, the Bill does not provide for a Code of Conduct for political parties. Finally, it does not provide for a tribunal in the event of a dispute over results. This despite the fact that the amendments were proposed primarily to avoid court challenges and election recounts (Lebeau \& Dima, 2005, p 4).

\section{CAMPAIGNING}

A critical component in the acceptance of the outcome of elections is the quality of the electoral contest. Campaigning in Namibia is guided by an electoral Code of Conduct, put in place in 1999 and prescribing the 'rules of campaigning'. Most notably, the Code of Conduct prohibits contestants from using language which may be construed as inciting violence in any respect.

With the exception of the South West African National Union (Swanu), which started its campaign in August 2008, serious campaigning only started in October 2009.

A preliminary observation about the 2009 election campaign is that the policy distinctions between the different parties offered limited insight into their popularity. For this reason the process was based on personalities rather than on issues. Election manifestos should provide the electorate with insights into the parties and their programmes. However, in the case of Namibia, the reliance on personalities, the recreation of the independence moment and, in some cases, ethnic affiliation seem to play a much more prominent role than election manifestos.

Not surprisingly, while they diverge in their approaches, two analysts, Links (2009) and Maletsky (2009) came to the same conclusion: that manifestos 
play a minimal role in voters' choices. Du Pisani \& Lindeke (2009, p 13) believe that election manifestos are redundant as electioneering tools because, for Swapo: 'Independence, peace, a functioning democracy, a mixed economy and reconciliation make for a powerful template of factors that constrain and close political space for opposition parties.'

One of the most contentious issues of the 2009 elections and the campaigning process relates to the national broadcaster, the Namibian Broadcasting Corporation (NBC). The role of the media during an election is critical because they serve as a conduit between those standing for political office and the general public. Media coverage of political party activity becomes, therefore, intimately related to a free and fair electoral process.

In Namibia, the Communication Commission Act decrees that 60 per cent of free public service campaign coverage on radio and television be divided proportionally according to party representation in the National Assembly. The Act further states that the remaining 40 per cent should be shared equally between all parties contesting the elections. However, as in 2004, opposition parties complained that the NBC's coverage was biased towards Swapo. As Table 1 illustrates, the NBC is regarded in Namibia as a reliable conveyer of news. More than 80 per cent of respondents believe the national broadcaster serves as an invaluable source of information.

Table 1

Public trust in the media (percentages of respondents)

\begin{tabular}{|l|r|r|r|r|r|r|}
\hline & $\begin{array}{c}\text { Never } \\
\text { trust }\end{array}$ & $\begin{array}{c}\text { Sometimes } \\
\text { trust }\end{array}$ & $\begin{array}{c}\text { Most } \\
\text { times } \\
\text { trust }\end{array}$ & \multicolumn{1}{|c|}{$\begin{array}{c}\text { Always } \\
\text { trust }\end{array}$} & $\begin{array}{c}\text { Have not } \\
\text { heard } \\
\text { enough }\end{array}$ & Totals \\
\hline NBC & 2 & 10 & 30 & 55 & 3 & 100 \\
\hline Newspapers & 4 & 17 & 28 & 35 & 16 & 100 \\
\hline
\end{tabular}

Source: Keulder (2002)

A study conducted by Blaauw \& Van Rooyen (2009) suggests that there is evidence to support the views of the opposition. Figure 1 shows the amount of airtime political parties received during their 2009 election campaigns. Generally, the NBC allocated an average of 19.28 minutes. Closer scrutiny reveals that Swapo used 140.8 minutes. In contrast, its closest rival, the RDP only used 11.47 minutes, while the NMDC received the least coverage. The blurring of party and government roles, which, at times, intertwined, could be the reason why Swapo received more 
coverage than other parties. Simply put, government ministers do, at times, use supposed government coverage time to convey Swapo's message.

Ostensibly in response to this, and as a result of an application by opposition parties to the High Court, served on Friday 6 December 2009, the national broadcaster decided to cut the provision of free time to political parties (The Namibian 2 November 2009). This chain of events is reminiscent of a similar situation that unfolded in 2004, when the national broadcaster admitted that it had misled the public by claiming that the allocation of airtime on radio to political parties was guided by the Communications Act (The Namibian 27 October 2004).

The perceived bias of the NBC towards the ruling party also did not go unnoticed by electoral observers from the Southern African Development Community (SADC). While praising the coverage provided by the private media prior to the elections, the SADC observer team criticised the NBC for this bias (The Namibian 2 December 2009). The Pan-African Parliament (PAP) criticised the public broadcaster even more severely, accusing it of bias towards the ruling party and suggesting that state media in Namibia be separated from direct government control (The Namibian 3 December 2009).

\section{Figure 1}

Total time (in minutes) allocated by the NBC to political parties for electioneering from 19 October to 25 November 2009

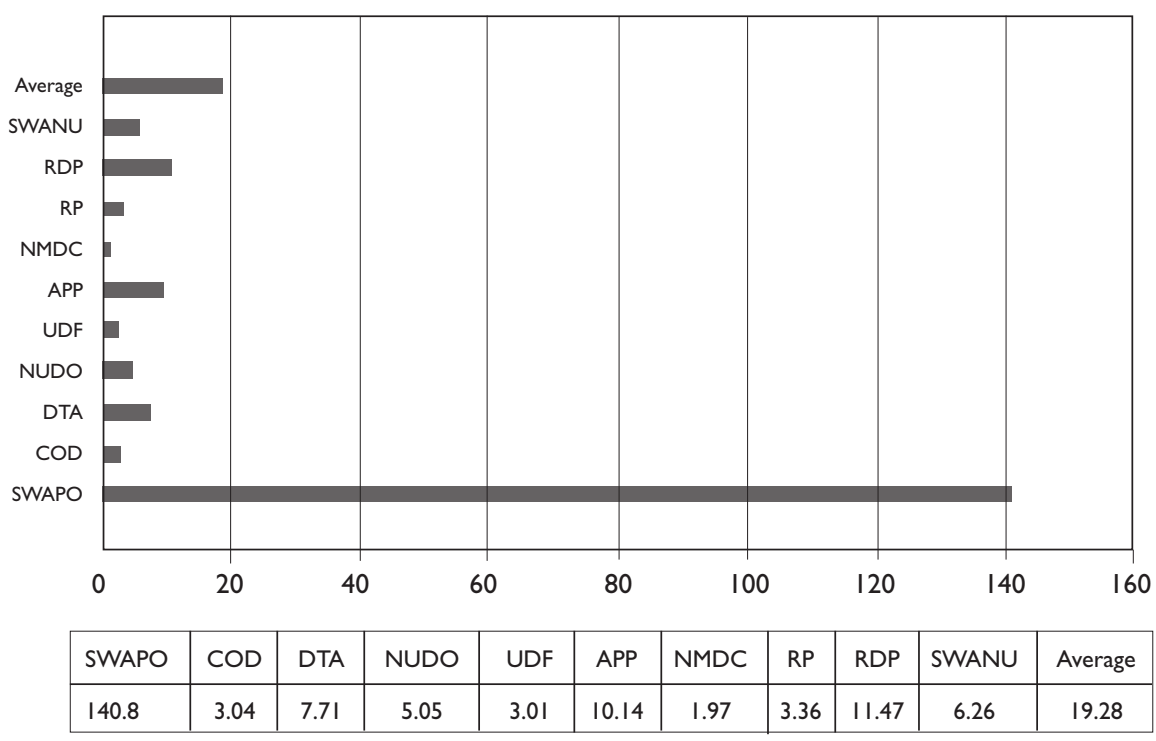

Source: Blaauw \& Van Rooyen 2009 
As in 2004 television programmes and advertisements relating to the elections were prepared and broadcast on NBC TV and One Africa Television and, through the Twilight Broadcasting Company, on television sets in public places such as banks, post offices, municipal offices and in some government ministries and departments. Local independent newspapers such as The Namibian, Republikein, the Windhoek Observer and local magazines such as The African and the Big Issue also played a useful role in ensuring public awareness of the elections

Another significant point in the 2009 election campaign process was that the formation of the opposition RDP, as had the establishment of the CoD, relegated policy concerns to the sidelines. The level of political tolerance during the 2009 campaign became a focal point. While at a presidential level calls were made for a peaceful and non-provocative campaign, the build-up to the elections was marked by violence and intimidation, particularly of members of the RDP. Such violence and intimidation had been reported by the RDP since the start of 2009 . Two incidents in particular indicate the level and degree of such violence and intimidation.

On 13 November 2009 there was a tense standoff between Swapo and RDP supporters in the Orwetoveni surburb at Otjiwarongo, which was defused by the police (The Namibian 13 November 2009). Prior to this the police confiscated eight pistols, a shotgun, nine knives, four machetes, a hammer, and an axe, among other weapons, from people going to a RDP rally at Outapi. Three people were arrested during the clashes in the town (The Namibian 8 November 2009). These incidents indicate that political tolerance in Namibia is low, a factor that must be addressed if the process of institutionalising electoral democracy is to take root.

\section{THE RESULTS}

Members of Namibia's legislature, the National Assembly, are elected by proportional representation, with each party nominating a list of candidates. There are 72 seats in the National Assembly and the president has the power to appoint up to six additional non-voting members. The seats are distributed according to a quota determined by dividing the total vote by the number of elected seats. The total number of votes received by each party is divided by the quota, to give them a preliminary share of the seats. Any seats left over are allocated according to the highest remainder method. 
Table 2

Turnout for the 2009 elections

\begin{tabular}{|l|c|c|}
\hline Region & Total 2004 & Total 2009 \\
\hline Foreign Missions & & 23638 \\
\hline Caprivi & 29164 & 63189 \\
\hline Erongo & 64784 & 22383 \\
\hline Hardap & 30603 & 33633 \\
\hline Karas & 39509 & 198035 \\
\hline Khomas & 140145 & 29217 \\
\hline Kunene & 28709 & 102430 \\
\hline Ohangwena & 89993 & 63114 \\
\hline Okavango & 80045 & 26747 \\
\hline Omaheke & 29729 & 104880 \\
\hline Omusati & 96408 & 84937 \\
\hline Oshana & 72670 & 73596 \\
\hline Oshikoto & 68882 & 51335 \\
\hline Otjozondupa & 57558 & \\
\hline
\end{tabular}

Source: The Electoral Commission of Namibia 2005 and 2010.

Table 3

Voter registration 2004 and 2009

\begin{tabular}{|l|r|r|}
\hline Region & Total 2004 & Total 2009 \\
\hline Foreign Missions & & 41799 \\
\hline Caprivi & 36592 & 92171 \\
\hline Erongo & 73686 & 45586 \\
\hline Hardap & 42396 & 52951 \\
\hline Karas & 46953 & 198035 \\
\hline Khomas & 159415 & 47837 \\
\hline Kunene & 37558 & 126133 \\
\hline Ohangwena & 102226 & 118877 \\
\hline Okavango & 100242 & 44251 \\
\hline Omaheke & 29729 & 133256 \\
\hline Omusati & 109408 & \\
\hline
\end{tabular}




\begin{tabular}{|l|c|c|}
\hline Oshana & 82183 & 104530 \\
\hline Oshikoto & 77019 & 93640 \\
\hline Otjozondupa & 72322 & 82736 \\
\hline
\end{tabular}

Source: The Electoral Commission of Namibia 2005 and 2010.

Voter turnout in 2009 was less than that in 2004 - 1812600 fewer people voted. The turnout was significantly lower in regions like Hardap, Karas, Khomas and Okavango. However, in Ohangwena the number who voted increased from 89 933 in 2004 to 102430 in 2009. The percentage poll was 68.64 compared to almost 85 per cent in 2004 .

Table 4

National Assembly results 2009

\begin{tabular}{|c|c|c|c|}
\hline Party & Votes & $\%$ & No of seats \\
\hline $\begin{array}{l}\text { South West Africa People's Organisation } \\
\text { (Swapo) }\end{array}$ & 602580 & 74.29 & 54 \\
\hline Rally for Democracy and Progress (RDP) & 90556 & 11.16 & 8 \\
\hline $\begin{array}{l}\text { Democratic Turnhalle Alliance of Namibia } \\
\text { (DTA) }\end{array}$ & 25393 & 3.13 & 2 \\
\hline $\begin{array}{l}\text { National Unity Democratic Organisation } \\
\text { (NUDO) }\end{array}$ & 24422 & 3.01 & 2 \\
\hline United Democratic Front of Namibia (UDF) & 19489 & 2.40 & 2 \\
\hline All People's Party (APP) & 10795 & 1.33 & 1 \\
\hline Republican Party of Namibia (RP) & 6541 & 0.81 & 1 \\
\hline Congress of Democrats (CoD) & 5375 & 0.66 & 1 \\
\hline South West Africa National Union (Swanu) & 4989 & 0.62 & 1 \\
\hline Monitor Action Group (MAG) & 4718 & 0.58 & 0 \\
\hline Democratic Party of Namibia (DPN) & 1942 & 0.24 & 0 \\
\hline $\begin{array}{l}\text { Namibia Democratic Movement for Change } \\
\text { (DMC) }\end{array}$ & 1770 & 0.22 & 0 \\
\hline National Democratic Party (NDP) & 1187 & 0.15 & 0 \\
\hline Communist Party $(\mathrm{CP})$ & 810 & 0.10 & 0 \\
\hline Rejected Ballots & 10576 & 1,30 & \\
\hline Total & 811143 & 100 & 72 \\
\hline
\end{tabular}

Source: The Electoral Commission of Namibia 2010 
Two events that preceded the announcement of the results of the 2009 elections heightened expectations that Swapo would be returned with a reduced parliamentary majority. These were the establishment of the RDP by former prominent members of the ruling party and the fact that young people, known as the 'born frees', were eligible to vote for the first time. The latter was considered to be of critical importance because, unlike previous generations, the 'born frees' did not have the degree of attachment to the ruling party discernible amongst older voters (Afrobarometer 2009, p 1).

In the event, the formation of the RDP and its performance in the elections did not lead to a significant challenge to the ruling party. What did happen, however, is that the newly formed party became the official opposition, not only displacing the COD as the official and leading opposition party, but also managing to gain a sizeable number of voters who had previously voted for that party.

Swapo won 54 seats in 2009, as opposed to 55 in 2004, and, as in preceding elections, more than 60 per cent of its support came from the northern regions, Ohangwene, Omusati, Oshana and Oshikoto, which constitute the former Owamboland, from which, historically, the ruling party emanates.

\section{- REFERENCES}

Adejumobi, S. 2000. 'Elections in Africa: A Fading Shadow of Democracy?' International Political Science Review 21(1).

Bauer, G. 1999. 'Challenges to democratic Consolidation in Namibia'. In R Joseph (ed). State, Conflict and Democracy in Africa. Boulder: Lynne Rienner Publishers.

Blaauw, L \& G van Rooyen. 2009. Report on the Election Coverage of the 2009 Presidential and Parliamentary election by the Namibian Broadcasting Corporation. Windhoek: Namibian Broadcasting Corporation.

Du Pisani, A \& B Lindeke. 2009. Political Party Life in Namibia: Dominant Party with Democratic Consolidation. IPPR Briefing Paper No 44, Windhoek.

Electoral Act 1992.

Electoral Amendment Act 1998.

Institute for Public Policy Research. March 2009. Namibia Political Party Prospects Leading to the 2009 Elections.

Keulder, C. 2002. Public Opinion and the Consolidation of Democracy in Namibia. Afrobarometer Paper No 15. Cape Town: Idasa.

Lebeau, D \& E Dima. 2005. Multi-Party Democracy \& Elections in Namibia. EISA Research Report No 13.

Links, F. 2009. 'Choices what choices?'. The Namibian, 11 September. 
Maletzky, C. 2009. 'Not worth the paper they are written on?'. The Namibian, 14 October.

Melber, H. 2009. Namibia's Elections 2009: Democracy without Democrats. Cape Town. Hans Boll Foundation.

Mozaffar, S. 2002. 'Patterns of Electoral Governance in Africa's Emerging Democracies'. International Political Science Review 23 (1).

Namibian, The, 27 October, 2004.

- 16 November 2007.

- 21 September 2009.

—_, 2 November 2009.

—_, 8 November 2009.

- 13 November 2009.

——, 8 March 2010.

New Era, 30 July 2009.

Tötemeyer, G, A Weehmhörner \& H Weiland (eds). 1996. Elections in Namibia. Windhoek: Gamsberg Macmillan Publishers.

United Nations Development Programme. 2000. Electoral Management Bodies as Institutions of Governance. New York: UNDP. 